\title{
Paving the Way for Pentecostalism: A Historical Exploration of Post-Reformation Revivals in Norway
}

\section{Anne Stensvold}

The first European country that was introduced to Pentecostalism was Norway. In 1906, a Methodist minister returned from a trip to the United States where he had by chance, so the story goes, become caught up in this intense new form of Christianity, a form which gave him hopes of a gigantic new revival to be shared among all Christians. The Pentecostals attracted attention through their strong millenarian expectations, but their most distinctive trait was the practice of speaking in tongues (Lie 2007; Ski 1981). On his return, the minister immediately started spreading the word, and within a few years, several thousand Norwegians had been struck by his message; Pentecostal congregations were established in almost every town in the country (Bloch-Hoell 1956; Lie 2007; Ski 1981). In this emic and biographical narrative, the triumph of Pentecostalism is accredited to the heroic efforts of one man, the former-Methodist-turned-Pentecostal pastor Thomas Ball Barratt (1862-1940). From a historical perspective, however, the arrival of Pentecostalism in Norway cannot be reduced to the story of one man's achievements. In order to make sense of the narrative, we need to understand the religious landscape in which Pentecostalism arrived.

A. Stensvold $(\bowtie)$

IKOS, University of Oslo, Oslo, Norway

(C) The Author(s) 2018

J. Moberg, J. Skjoldli (eds.), Charismatic Christianity in Finland, Norway, and Sweden, Palgrave Studies in New Religions and Alternative Spiritualities, https://doi.org/10.1007/978-3-319-69614-0_2 
As already mentioned, the first Pentecostal preacher in Norway was originally a Methodist minister. This is significant. The fact that he traveled to the United States in 1906 in order to ask for financial support from American Methodist congregations is also important, because it points to the strong relationships of economic dependence between congregations in the two countries. It also shows the results of earlier Norwegian-American contact, whereby American-influenced migrants had introduced Methodism five decades earlier. The financial aim of Barratt's mission was unsuccessful, as he returned without a penny; what he brought with him from America was inspiration - literally speaking - from the Pentecostal revival he had encountered "over there." In this sense, the story is emblematic because it shows how new and larger processes can be set in motion almost by chance, but it also demonstrates that the introduction of new revivals greatly depends on the history of previous movements and on social structures. Here was a Methodist pastor who unwittingly encountered Pentecostalism's different but also familiar message. We may say that Methodism provided the background that prepared Barratt for his encounter with Pentecostalism. In a similar manner, his own ministry provided a bridge to Pentecostalism for many others. When he went back to Norway to spread the "good news," he preached to Methodist congregations in which he was already known. In other words, Methodism offered an organizational network of congregations which allowed him to preach and secured him an audience across the country. More importantly, Methodism provided the theological concepts (e.g., sanctification through the Holy Spirit), looser liturgical structures, and enthusiastic preachers needed in order to make sense of the new message.

Religious change and innovation are complex processes, partly because religions often rely on exclusive notions. In a study of medieval Catholicism, Jean-Pierre Albert analyzes the process of making new saints. In order for a would-be saint to be recognized as holy, he argues, the new saint needs to tap into existing traditions and provide answers to present-day relevant questions, needs, and expectations. If a would-be saint fails to do so, he or she is regarded as either crazy or possessed (Albert 1997, 47-48). Inspired by Max Weber's ideal type of "the prophet," Albert points out that wouldbe saints pop up all the time, but only a few of them are taken seriously and become foci of devotion. For this to happen, the saint's new message must be better adapted to the existing social and emotional conditions of believers. The aspect of Albert's study that pertains to religious change is useful to the analysis in this chapter, because it helps clarify the significance of Pentecostalism in the Norwegian context, and it will thus be applied in the present analysis. 
I approach the establishment of Pentecostalism in Norway as an example of religious change, paying particular attention to national revivalist history. I begin by framing Norwegian Christianity historically. Starting with a brief account of the Lutheran state church after the Reformation (1536), I take a closer look at the late nineteenth century, when the first steps towards lifting the state's religious monopoly were taken (1845), up to the first decade of the twentieth century when Pentecostalism arrived (1906). It should be noted that these developments are not unique to the Norwegian case. Although each of the Nordic countries has its own history, the sequence of main events followed similar patterns-from Lutheran state churches to the start of the dismantling of religious monopolies in the 1800s, and the arrival of Pentecostalism in the first decades of the twentieth century. In this chapter, Norway serves as an example of these developments.

\section{The Monarch's Religious Power: The Protestant REFORMATION}

The Protestant Reformation was introduced by the Danish-Norwegian King Christian III in 1536. Regarding himself as the protector of the true faith, the king severed ties with Rome, appropriated church property and placed the church under his own rule. This is an important reason for the radical difference between the religious context in the Nordic countries and in American society, where Pentecostalism emerged. Whereas religion in the United States was established as a domain principally independent of state interference, religion in the Nordic countries was integrated in the state. The Lutheran state churches created during the Protestant Reformation were headed by their monarchs; priests were state employees, and the population had no choice but to loyally accept the king's rule. In the Nordic countries, Protestantism was introduced top-down, and the population was quite unprepared for the transformation from Catholicism to Protestantism (Schumacher 2005). In Denmark-Norway, the transition seems to have happened smoothly in the Norwegian part of the territory, as far as the written sources can tell. Apart from an account of an iconoclastic purge under Bishop Schjelderup in Bergen in the 1550s, there are no accounts of violent iconoclasm. This is not to imply that the population accepted the new form of Christianity with enthusiasm. The existence of the many pieces of Catholic art (e.g., crucifixes and statues of Mary) that have survived down to our times suggests that Protestant iconoclasm was neither systematic nor complete. Although devotional images were banned and church buildings 
thoroughly stripped of decoration, much Catholic art remained unharmed, hidden away by the local population (Rasmussen and Thomassen 2002). As far as the priests (and their wives) were concerned, they seem to have been readily accepted - not just as the heirs to Catholic clergy, but also as rightful local representatives of the crown.

The power of European kings to decide the religious affiliation of their subjects was legitimised by the Augsburg Agreement (1555), which contained the principle that the king should have the authority to decide which religion his people should belong to. This royal prerogative is known as cuius regio, eius religio, "whose realm, his religion." It was a pragmatic arrangement that monarchs could invoke to quell religious rebellion. As a consequence of the Augsburg Principle, people of different faiths were usually allowed to leave their country. This religio-political reality endured well until the mid-nineteenth century, when democracy was introduced, and people were gradually given greater ability to choose their own religious affiliations. Put bluntly, we may say that faith was democratized as it became a matter of individual choice and responsibility. The roots of this development can be traced back to the early stages of eighteenth-century Pietism, a theological and devotional innovation associated with the German Lutheran theologians Philip Jacob Spener and August Hermann Francke (Shantz 2013). Building on the mystical tradition from Johann Arnt and Jacob Böhme, the Pietists valued personal faith over religious convention, and religious experience over liturgical participation. Eighteenth-century Pietism changed the face of European Protestantism, so much so that it has been described as the final realization of Protestantism, and a logical conclusion of its critique of Catholic ritualism and outward moralism (Amundsen 2005). Pietism has also been described as an important early part of the "individual turn" in Western culture (Tylor 2007). At first, Pietism, with its emphasis on personal piety, was a movement among the clergy and the bourgeoisie, who were attracted to its Bible study, popular mysticism, and focus on prayer. By the end of the century, Pietistic devotion had spread to broader segments of the population, and was turning into a mass movement.

\section{Popular Pietism: Hauge and Norwegian Mainstream Religion}

In the nineteenth century, Pietism spread to the lower strata of society and gave rise to new, emotional forms of Christian devotion. This form of Pietism emphasized the idea of a universal priesthood of all believers, and put it into practice by arranging religious meetings at home (i.e., in locations 
other than church buildings), where lay people assembled for Bible study and prayer groups. As a consequence, the state church clergy started to lose control of religion, and the authorities regarded Pietism as a threat to the existing religious order. In order to put a stop to this development, a new law was introduced in 1741, which banned unauthorized preaching-the Conventicle Act (Konventikkelplakaten). In the kingdom of DenmarkNorway, all such meetings without the presence of a state church priest were illegal, but the religious ideas associated with Pietism did not disappear; they re-emerged and gave rise to popular forms of devotion at the turn of the nineteenth century.

Popular Pietism had a distinctively collective aspect, with its closely knit study and prayer groups that would meet clandestinely in peoples' homes, now in defiance of national law. No doubt, the fear of repercussions helped turn these groups into particularly close communities. To the authorities, their activities undermined the state church, and several lay preachers were punished with prison sentences. The most important among them, lay preacher Hans Nilsen Hauge (1771-1842), was imprisoned for years, but kept in touch with his associates via letters, and secretly published books (Christoffersen 1996; Gilje 1995). For eight years (1796-1804), Hauge traveled widely across the country and preached the need for repentance, criticized state church priests for their lack of true and heartfelt faith, and elaborated on the concept of faith as total trust in the Almighty. He became a national figure through his books and letters, which were copied and secretly circulated among his followers, called "friends" (venner).

Hauge's "friends" comprised both women and men, and formed an informal network that spanned the country and which, until 1842, remained illegal (Amundsen 2005). Formally, they acknowledged the state church, followed its precepts, and attended church on Sundays, but their personal faith was defined by Hauge's brand of popular piety. These followers were also known as "readers" (lesere) for their frequent use of the Bible, and were mostly recruited from the poorer strata of the farming population. Through their participation in the movement, they received training in literacy, the importance of which should not be underestimated. In fact, some of Hauge's "friends" were industrial entrepreneurs; some of the first printing presses and weaver mills in the country were initiated by Hauge and his "friends" (Greve 2011). However, this enterprise was also one of the main reasons for the state church priests' irritation with Hauge (Gilje 1995), since it provided him and his "friends" with economic autonomy to pursue their mission and spread the Word, and challenge the religious monopoly of the 
state church. Hauge was imprisoned for 10 years (1804-1814) in an ineffective attempt to curb his influence. To some extent, this harsh treatment may have influenced him to speak less critically of the state church. In the last years of his mission, Hauge encouraged his followers to attend church services regularly and remain loyal to the state church. This would eventually diminish tensions between the church and the Haugian movement, which later resulted in the establishment of the Inner Mission (Indremisjonen), a gigantic attempt to "convert" the Norwegian population (99 percent of whom were members of the state church) to Hauge's brand of Protestant Christianity, an effort to which we will return later in this chapter.

The religiosity promoted by Hauge can be summed up, although somewhat crudely, as a combination of three main components: First among these are emotionally oriented elements, exemplified by Hauge's reported visions of Christ. Second is an acute sense of one's inherent sinfulness. Third is an emphasis on individual submission to God, commonly referred to as "receiving Christ." The need for repentance found expression in a severe moral code that emphasized honesty and hard labor, and banned all forms of entertainment, including dancing, card games, and alcohol consumption. Hauge's books were not only read by his followers, but were also studied by church authorities, and discussed by university theologians. Eventually, they gave rise to heated theological debates and two parallel cultures in the national church: one focusing on tradition, authority, and rituals, and the other inspired by Hauge. Socially, ritually, and intellectually, Haugian piety redefined mainstream Norwegian Christianity.

\section{The Dismantling of Religious Monopoly AND THE Rise of THE INNER Mission}

State officials' attempts at stopping Haugian Pietism proved ineffective. After several decades of unlawful religious activities outside the state church, the law against lay preaching was abolished in 1842 (Oftestad 1998). In the same liberal vein, the Catholic Church was allowed to re-establish itself in Norway in 1843, through a special provision to cater to Catholic foreigners. This was a delicate affair in which the apostolic vicariate, Monsignor Laurentius Studach, who was closely associated with the royal family, played an active part in getting the king's support for establishing a Catholic congregation in Norway (Gran et al. 1993). It was intended exclusively as a service for foreigners, and according to the Norwegian Constitution (1814), Catholics were not allowed to conduct 
missionary work in Norway. This was rooted in deeply seated prejudice against Catholicism, an attitude that is amply illustrated by the fact that Jesuits were not allowed entry to the country until 1956.

Two years later, in 1845, the Dissension Act (Dissenterloven) was passed, which allowed "free" (i.e., nonstate) churches to establish themselves in Norway. The law, which made religious individualism a legal principle, allowed persons above the age of 25 (age of majority) to abandon the state church and take up membership in free Christian congregations. This was an important step towards dismantling the state monopoly on religion. It was also a decisive legal invention, which detached membership of the Norwegian state church from Norwegian citizenship (Oftestad 1998). An immediate consequence was that a number of Free Churches were founded in the following decades. Most of them were small local groups, and were comprised of between a couple of hundred to 1000 members. Most of these groups were critical of the state church, especially the subordination of religion to the power of king and state. Some criticized infant baptism, such as The Free Evangelical Congregations (De Frie Evangeliske Forsamlinger; Froholt 1993), and the centrality of the Eucharist, for example "the Lammers Movement" (Lammersbevegelsen; Øverland 1981).

However, despite this relaxation of the legislation, religious freedom was not yet realized, since only Christian and Jewish groups were allowed to establish themselves (Stensvold 2005c: 370-373). The state invested considerable resources in maintaining control. Partly inspired by Hauge and relying on his network of "friends," the Inner Mission (Indremisjonen) was established by state church priests in 1855 . From the $1850 \mathrm{~s}$ and ' $60 \mathrm{~s}$ onwards, this initiative would grow into a folk movement (Gundersen 1996). The aim was to reach the entire population and create a fundamental change in folk piety; the movement involved a novel message clad in recognizable religious language. The Inner Mission's ideology and activities are significant, as they can be seen as a state response to independent revivals by the creation of local movements, by means of which it could thus exerting its own influence in shaping the state church from below.

The first generation of the Inner Mission's traveling preachers (emisserer) was recruited from among the "friends" (Amundsen 1995). In this way, we may say that Hauge's heritage became the basis for a form of popular piety that eventually gained state sanction and united Norwegian clergy and large segments of the population in a shared vision of Christianity. It was an emotionally charged faith, motivated by an acute awareness of inescapable 
sinfulness. It was solemn, meek, and morally severe, with a complete ban on "unchristian" entertainment. In short: immoral behavior was interpreted as signs of damnation, and the Inner Mission offered the route to salvation. Teetotalism and charitable work became popular in local communities as well as in towns. By the end of the century, an estimated 20 percent of the population was part of the Inner Mission. During the first decades of the twentieth century, the popularity of the movement reached a peak, marked by a massive increase in the number of local Inner Mission groups, accompanied by a significant rise in the number of "prayer houses" (bedehus). Although an integral part of the state church, the Inner Mission represented an alternative, austere type of religiosity, and stressed equality among its members instead of subordination to church authorities. The prayer houses were owned by the local groups, which gave the members an important sense of participation (Aagedal 1986). Here, the Inner Mission would hold meetings, also on Sundays, at which communal prayer, singing, and coffeedrinking offered popular alternatives to the state church rituals.

\section{Migrants And Missionaries}

The gradual deterioration of the religious monopoly coincided with other major changes in Norwegian society, notably industrialization, urbanization, and the migration of impoverished farmers to North America. In only three decades, from 1860 to 1890 , almost one fourth of the Norwegian population emigrated. Whereas many of the first migrants were religiously motivated to seek refuge "over there" - among them Quakers and Hauge's "friends"-poverty and new opportunities for obtaining material wealth were motivational factors for the mass emigration. In the United States, the Homestead Act (1862) enabled immigrant farmers to obtain ownership by cultivating new soil, and when the Civil War (1861-1865) came to a close, mass migration from Norway began (Østrem 2006). For the "old country," the exodus was not entirely a story of a lost generation, but also had a positive effect, since it decreased the effects of overpopulation and opened up Norwegian culture to foreign influences. Books and letters provided "a wealth of practical information along with their advocacy of American conditions," which added to the interest called America-fever (Mauk 2013, 135). But most of all, letters to family and friends increased general knowledge of life "over there" and familiarized Norwegians with the religious ideas and practices that migrants encountered. As a result, North America seemed closer and thus more familiar to those left behind. 
The religious landscape encountered by the migrants differed substantially from that of the Nordic countries. The United States was considerably more pluralistic; among the declarations enshrined in the First Amendment to the Constitution were freedom of religion, freedom of speech, and separation between church and state. This enabled competition between a wide variety of different churches and groups. Significantly, religious freedom was based upon an understanding of faith as an individual's relationship to God, and construed as a private privilege. Charles Taylor (2007) calls this a change in "the conditions of belief," whereby the authority of the individual reigns in religious matters.

At the time Norwegian and other Nordic immigrants arrived, the United States was ripe with fervent activity in the aftermath of the Second Great Awakening's gigantic revival meetings (ca. 1790-1830), religious ardor, and millenarian belief. Many immigrants' letters described these events. Even more important were migrants who returned to the "old country," bringing their impressions with them. Some of these migrants returned as missionaries. Focusing their activities on new industrial towns, they had easy access to the working-class population, who were more receptive to their mission; the countryside was virtually closed to them unless they knew the addresses of friends and families who could vouch for them to the local priest. Although the Dissension Act (1842) legalized lay preachers, legal and practical obstacles still limited their sphere of activity. Outdoor gatherings were not allowed, which meant that preachers of various kinds had to find other venues for meetings, usually in private homes. This placed serious practical impediments on traveling preachers, who were totally reliant on well-established personal contacts. These restrictions did not apply to the same extent in the growing cities, where strangers were not as conspicuous, and where one open door could suffice as a platform for starting missionary activities.

The history of Methodist missionary Ole Peter Petersen well illustrates the strong dependence on personal networks for missionary activities. Petersen started his ministry in his birthplace, Fredrikstad, a small industrial town in the southeastern part of the country, where he first contacted local people who he knew would be open to new religious ideas. Petersen focused his preaching on younger members of the working class, who were receptive to his message of personal faith, as well as his emotional style of peaching (Hassing 1981, 72). Yet the American-influenced missionaries like Petersen did not have an easy task; they were met with skepticism, and sometimes even open hostility, by official authorities. For example, in Halden, another 
small town in southeastern Norway, one local priest managed to stop Methodist meetings on the grounds that they collided with Sunday church services (Hassing 1981, 81). Many state church priests also reacted strongly against what they saw as the missionaries' distorted image of Christianity. In 1876, a state church priest in Bergen, whose daughter had joined the local Baptist community, initiated a smear campaign in the newspapers, targeting Baptists and charging them of attracting naïve adherents by promising salvation (Eidberg 1981, 67). The history of Mormonism, or the Church of Jesus Christ of Latter-day Saints, adds to the same story of local hostility. The Mormon Church was actually the first religious organization of United States origin established in Norway (1852), with branches in the coastal towns of Risør, Brevik, and Fredrikstad. Only a year later, these were closed on the grounds that they were not Christian because, in addition to the Bible, members recognized the Book of Mormon as a revealed and authoritative sacred scripture (Stensvold 2005b, 347).

\section{Missionaries to Norway and a Discussion of Labels}

Missionaries coming to Norway, a significant number of whom were returning Norwegian migrants, emphasized faith in Jesus and his ability to change the inner person and deliver believers from sin, thereby making them holy and restoring them to an original state of grace through the agency of the Holy Spirit. Theologically, this understanding of grace was introduced with Methodism, but with the American revival movements (the Great Awakenings) in the eighteenth and nineteenth centuries, it became an integrated characteristic of what came to be known as the Holiness Movement. The Second Great Awakening (1790-1830) also introduced a powerful new mode of assembly that came to dominate the emerging movements; mass meetings or camp meetings attracted large crowds and many formerly passive believers. These meetings centered on an enthusiastic and emotional form of preaching, designed to cater to what the preachers considered to be the needs of their largely uneducated and socially uprooted audiences (Lambert 1999).

The returning migrant missionaries were inspired by the Wesleyan idea of holiness or "Christian perfection," preaching that it was possible for people to live a life permeated by holiness: the combined result of faith, grace, and regeneration. Unlike the Inner Mission's brand of Protestant revivalism, the American-influenced preachers believed that the end of the world was imminent, giving their message a sense of urgency and this, 
being new and strange to some, was new and refreshing to others. Their preaching had an acute sense of haste and fear of being "left behind" when the Savior returned to save his own at the Second Coming (Harding 1993). These ideas were revolutionary to Norwegians, who had been raised in the state church tradition and taught by the local priest to respect authority, and hope for God's mercy at the Final Judgment. They were now told that the only way to salvation was to repent of their sins, contemplate the consequences of those sins, and ask God's forgiveness. There were also great differences in sermon delivery and style: whereas American and Americaninfluenced preachers were optimistic and self-assured, Norwegian Inner Mission preachers embodied an inward-gazing kind of religiosity. They also had a different sermon style. Traveling preachers from the Inner Mission and preachers from the domestic Norwegian Free Churches (e.g., The Lamb's Revival [Lammets Vekkelse] and The Free Apostolic Christian Community [Den Frie Apostoliske Christelige Menighet]) emphasized repentance, and would typically ask their listeners to start the day by examining their conscience, cautioning them to be aware of their sinful character. Naturally, there were several other differences between the American and American-influenced preachers, but these particular features set them apart from the existing religious context in Norway.

The fact that the new missionaries belonged to churches with roots in the revivalist movements of the Great Awakenings gave United Statesbased Protestant Christianity a distinct character: a culture of devotion and a special brand of preaching. In scholarly literature, various terms are used to emphasize these characteristics: folk religion or lay Christianity, popular Pietism, born-again Christianity, and Evangelicalism (Hackett and Lindsay 2008). The latter term most frequently refers to theologically conservative Protestants. Mostly, "Evangelical" does not include Pentecostals, while at other times it largely overlaps with what used to be referred to as Fundamentalism (Casanova 1994). However, it is problematic to directly apply the term "Evangelical" to the Norwegian context without pointing out important differences; the term's connotations in the American context differs from those it has in the Norwegian one. The meaning of the term "Evangelical," which in Norwegian is evangelisk, derives from the Latin word for "gospel," evangelium. Rather confusingly, the Norwegian constitution contains a reference to the state church as "the Evangelical-Lutheran religion" (Evangelisk-Luthersk religion). In the constitution, the word signifies the Norwegian state church's Protestant identity, or more specifically its foundation on the gospel (evangelium). 
This usage differs from evangelikal, a term that refers to a particular kind of revivalist church or congregation. Whereas the Norwegian distinction between evangelisk and evangelikal has no parallel in English, it is worth noting that evangelisk is construed in opposition to Catholic, whereas evangelikal refers (in Norwegian usage) to those congregations that emerged from the Great Awakenings. In this chapter, the term "American-influenced revivalism" is used to accentuate the special nature of these movements in a different cultural and regional setting. This equips us with categories that are useful for discussing similarities and differences in relation to NorwegianUnited States contacts and earlier revivalist movements in the Norwegian context and, most importantly, enable us to see Pentecostalism as a part of a larger history of American-Norwegian revivals.

\section{The First Wave: Methodists and Baptists}

The relaxation of legislation in the 1840s enabled competition between state-employed priests and various independent traveling preachers. Soon thereafter, American and Norwegian returning migrants started to arrive. Over a period of 50 years, these missionaries arrived in three waves. The first-Methodists, Baptists, and Mormons-came to Norway in the $1850 \mathrm{~s}$ and '60s. From the state church officials' point of view, they posed a serious threat, and the priests did what they could to maintain their own status as custodians of the "true religion." Yet, in spite of ridicule and practical difficulties, these missionaries were able to develop viable and lasting institutions by presenting their forms of Protestantism as attractive alternatives to that of the state church.

Methodism was first introduced in 1853, by returning migrant and former seaman Ole Peter Petersen, who had been sent on an official mission by his church in the United States - the Methodist Church of America-to establish a congregation in his hometown Fredrikstad. Petersen brought with him an optimistic and apparently appealing message: In order to achieve salvation it was enough to want it, to desire to believe in Christ. In 1884, 4418 Methodists were registered in Norway, more than twice the number of Baptists (2132), and Methodism formed the largest Christian body outside the state church. In his presentation of Methodism in Norway, scholar of religion Arne Hassing includes a list of members at the end of the nineteenth century, which shows a pattern shared with other Americaninfluenced churches and denominations: In the beginning, a large majority of the recruits were young manual laborers, factory workers, day laborers, 
and servants (Hassing 1981, 85). Moreover, a significant part of the membership consisted of widows and unmarried young women employed in domestic work.

The Methodists placed great emphasis on diaconal efforts and they offered members the security of a tight-knit community (Hassing 1981). The social aspect was important in a cultural context rife with prejudice. In addition to hostility and mockery, people outside the state church were subjected to systematic discrimination. For example, dissidents from the state church were banned from work as state employees. The ban was lifted gradually: In 1878 dissenters could be accepted as army officers, in 1891 they could take up positions as state functionaries, and finally, in 1917, they were allowed to take up positions as teachers.

In 1857, Baptist Fredrick Ludvig Rymker (1819-1883), another former seafarer and returning migrant who had already preached in his native Denmark for seven years, decided to continue his work in Norway. Rymker converted in the First Baptist Mariners' Church in New York in 1845. When he first started his missionary work in Denmark, which he engaged in from 1850 to 1857 , he received financial support from the Bethel Union in New York. He also worked as a shoemaker to support his family. In 1857 Rymker arrived in Skien, a small industrial town on the east side of the Oslo Fjord, where he conducted his first baptism, on Christmas Day 1858. The first convert was a young man, only 18 years old, and below the age required for discontinuing state church membership (the age of majority was 25 years until 1858, when it was reduced to 21 years of age). Rymker feared that it would be judged a criminal offence, but the baptism, which took place on an ice-covered river and created quite a stir, was ignored by the authorities. In 1860, Rymker established the first Baptist congregation in Skien. The majority of the converts came from a local Norwegian revivalist group, which shared the Baptist criticism of infant baptism, but otherwise was closer to the Inner Mission and Hauge's heritage.

After 10 years of missionary work, 15 Baptist congregations had been established in towns all over the country, even as far north as Tromsø. Swedish Baptists helped out with missionary work, but contacts with the United States nevertheless remained vital. The strength of connections between Baptists in Norway and the United States is clearly illustrated by the fact that a school offering formal training for Scandinavian Baptist pastors was established in Morgan Park near Chicago in 1884. This arrangement lasted until 1910, when a similar institution was opened in Oslo. Membership numbers in Baptist congregations in Norway reached a peak 
in the years following World War II, with 7500 members at the end of the 1940s (Eidberg 1981; Mikalsen 1993).

In the 1870s, the average age in Baptist congregations was 35 years, with a large majority of women (Eidberg 1981). Similarly to its Methodist counterpart, the female majority was mainly made up of single women working as servants, but there were also widows, and some married women whose husbands were away at sea. The rest were married men, mostly manual laborers. Economic deprivation was not the primary motive for joining the new movements; rather, it was social isolation and a need for a community of like-minded individuals. Viewed like this, this brand of Americaninfluenced Protestantism, with its emphasis on emotional preaching and its social engagement, had much to offer. With its focus on holiness, grace, and the promise of salvation, Baptism presented an attractive alternative to the Inner Mission's call for self-criticism and seriousness.

\section{The Second Wave: Adventists AND JEHOVAH'S WITNESSES}

The message of Methodists and Baptists was sometimes hard to distinguish from that of the Inner Mission, as they all stressed conversion and warned against the consequences of alcohol and extramarital sexual relationships. On the other hand, the dramatic eschatologies of Adventists and Jehovah's Witnesses were something new. The first Adventist preacher arrived in Kristiania (now Oslo) in 1879 and was of Danish origin. The eschatological aspect was not as central to Norwegian Adventists as it had been when Adventism first emerged in the United States in 1833. William Miller, a Baptist preacher in upstate New York, declared that the Second Coming and the end of the world would occur in 1844. When this prediction failed, the dominant interpretation was that Christ had indeed returned as predicted, but instead of introducing an imminent end of the world, he had initiated the process that would eventually lead to the end of our times. In the 1870s, the prediction was that the end would come on October 22, 1914. Nevertheless, Adventists in Norway were soon associated with other Adventist features such as focusing on the body as "the temple of the Holy Spirit," and with various health practices such as bathing and vegetarianism (Kvinge and Næsheim 1993).

In 1892, Norway's first missionary from the Jehovah's Witnesses, Rasmus P. Hammer, settled in Bergen. Hammer was a returning Norwegian migrant and had been a Baptist minister in North Dakota (Ringnes and 
Sødal 2009). The beliefs of Jehovah's Witnesses differ from Christian mainstream theology in that they do not accept the Trinity, and argue that this dogma lacks biblical foundation. To them, Jesus Christ is the son of God and separate from, and subordinate, to the Father. On a similar note, they hold that the number of those who will be saved is a mere 144,000, the number given in the Book of Revelation (7: 3-8). Thus, they have shared the fate of the Mormons and have often not been recognized as a Christian church, even though they regard themselves as Christians and read the Bible in a particular, yet strictly literal way. Their teachings differ significantly from mainstream Lutheranism as well as from Methodism and Baptism, which are Trinitarian, and in which redemption is much less exclusive and is obtainable by everyone who has faith. The belief in predestination made the Jehovah's Witnesses appear especially severe, and in Norway they received criticism and faced outright hostility, particularly from many state church priests. Despite differing theological orientations, Adventist and Jehovah's Witnesses missionaries managed to establish congregations in Norway, and like the Methodists and Baptists, the members were mainly recruited from among the working classes in industrial towns. Although we lack official numbers for Adventists and Jehovah's Witnesses, a reasonable estimate would place their members as numbering between 1000 and 1500 at the turn of the century.

\section{The Third Wave: Pentecostals}

In 1906, the Pentecostal revival was still spreading in the United States. The very same year, this movement was introduced to Norway. Within two decades, Pentecostalism had become the largest of the American-influenced revivalist groups in the country. What made it so comparably successful? Looking at their teachings and religious practices, Pentecostals resembled the first wave of American-influenced Protestants, and shared the Adventists' eschatological expectations for Christ's second coming. However, the most distinctive trait of Pentecostalism-manifestations of the Holy Spirit in mystical and loud signs: speaking in tongues (glossolalia) —was an unknown religious practice in Norway and appeared to many as both fascinating and appalling. Although there are references to similar practices in the Bible, where it is described as a charisma, a "spiritual gift," speaking in tongues was promoted by Norwegian Pentecostals not just as a sign of divine presence, but as evidence of baptism in the Holy Spirit. When compared to the Inner Mission's stress on repentance and intense self-reflection, the 
Pentecostal message could provide a tangible answer to religious needs for the assurance of salvation, at least for those who realized the practice. Viewed from this perspective, the attraction of the Pentecostal message comes to the fore. The emotional impact of such an experience-receiving the Holy Spirit-was central to the spread of Pentecostalism. These experiences often occurred at mass meetings, and dramatic manifestations of faith became emblematic of the Pentecostal brand of American revivalism. Such gatherings became increasingly important in all sections of civil society from the 1880s onwards, as Norway developed into a democratic country in the modern sense of the word. Political mass meetings for voting rights, teetotaler rallies, and extensive and heated debates about everything from language and dialects to the legal status of children born out of wedlock, eroded the ban on mass gatherings and preaching in public. These factors may to some extent account for the relative success of Pentecostalism in Norway, but historical circumstances also need to be considered. Pentecostalism arrived in a country where other forms of Americaninfluenced Protestantism had prepared the way by establishing hopes of a revival soon to be realized. Pentecostalism was interpreted as that revival, which made its arrival a welcome event.

In the first decades of the twentieth century, emigration waned and the majority of emigrants were now city dwellers. Moreover, instead of entire emigrant families leaving, these emigrants were largely single men (Østrem 2006). This was a reflection of social changes that were taking place in Norway, particularly a new economic optimism, political liberation, and a significant increase in civil freedoms: Voting rights for all men regardless of economic status (1891), general suffrage for women (1913), and national independence from Swedish rule (1905) created a fervent cultural climate characterized by optimism (Sørensen 1998). Meanwhile, the state church, which still accounted for 98-99 percent of the population, struggled with passive members. These were the main features of the Norwegian historical context and religious landscape into which Pentecostalism was introduced. This was also a time of intense struggle among university theologians over the introduction of historical criticism in Bible interpretations. The struggle went far beyond academic milieus, and split the state church down the middle. However, no attempts were made to strengthen church attendance by modernizing church services or liturgical language. Instead, church representatives tried to appeal to people's sense of decency and duty as parents and responsible citizens (Klaveness 1901). At this point in time, American 
and American-influenced missionaries were well-known figures in Norwegian religious life, and Pentecostalism placed itself squarely within the existent contextual pattern of alternative Christianities.

\section{Thomas Ball BarratT}

The single most important agent behind the new movement was the already mentioned Methodist pastor Thomas Ball Barratt (1862-1940), who had traveled to the United States in 1906. Visiting New York, he heard rumors about a new revival that had started on Azusa Street, Los Angeles. Captivated by the vivid descriptions of speaking in tongues and encounters with the Holy Spirit, he sought these experiences for himself. On October 7, 1906, Barratt experienced a breakthrough, which he describes in the following way: "Hallelujah! It happened yesterday between 5 and 6 PM [...] My soul is burning. I believe I am the happiest man in the world. Everything is made new to me" (Barratt 1941, 101, author's translation). Barratt, however, did not interpret this experience as the baptism in the Spirit, but as a preparatory experience that opened him to the real baptism in the Spirit, which took place a month later, after days of intense prayer and theological discussions with friends and acquaintances. On November 15, he received the gift of tongues, alone in his room in the middle of the night $(1941,120)$. He describes it as a peaceful and deeply meaningful experience of being filled with light and speaking in unknown languages all through that night. These events were relayed to Norwegian Methodists in the autumn of 1906 through the Methodist monthly publication "The City Mail" (Byposten), which was edited by Barratt (The Azusa revival is described in no. 22, 1906). When he returned to Norway at the end of the year, his audience was already prepared for something exceptional. That Christmas, 10 people "received baptism in the Spirit, and five of us are singing in tongues" (1941, 134). Barratt himself described these first meetings as exciting events directed entirely by the Holy Spirit, at which singing, prayer, and witnessing occurred spontaneously, intermediated by long periods of silence. When referring to the gift of "speaking in tongues" he writes "singing in tongues" (1941, 136). The next years, Barratt preached in Methodist and Baptist congregations and traveled widely across Norway and other Nordic countries. However, the exact time of birth of organized Norwegian Pentecostalism is disputed (Bloch-Hoell 1956). The first congregation- "the Tabernacle" (Tabernaklet)—was established in Skien in 1908, but it was not until 1916 that Barratt became minister of a Pentecostal congregation: Filadelfia in Oslo. 
Although Barratt certainly played a key role in spreading Pentecostalism, it is difficult to identify causal factors for why it would catch on and in less than a decade have grown larger than the Methodist Church. Undoubtedly, however, it was largely due to timing. Except for its revivalist heritage, Norway in the first decade of the twentieth century was a young nation characterized by economic and social change, particularly industrialization and urbanization, as well as political optimism.

\section{Recruits, Community, and American Dreams}

Within 50 years of Barratt's return, Pentecostal congregations counted more members than the other American-influenced congregations altogether. Yet, no matter how one looks at it, Christian groups outside the state church were a relatively marginal phenomenon. The first convert to Baptist Christianity was baptized on Christmas Day in 1858, in a river filled with ice and snow. It must have been a strange sight to the freezing bystanders. The ritual was unknown to them; the place was usually associated with timber floating, and the convert, dressed in a white linen cloth, must have made a dramatic impression. But the strange ritual was emblematic of the drama that the first converts experienced. While the large majority of active Christians who sought personal transformation and religious experiences did so in the state church's Inner Mission, conversion to the American-influenced movements meant something else. Whereas a Baptist or Pentecostal conversion involved adult baptism (albeit not always on a river in midwinter), the Inner Mission's idea of conversion was a quiet, inner experience, thought to manifest itself after the spiritual event, in a moral way of life. For those who joined the new movements, conversion also involved dramatic social and organizational change. Becoming a member of one of the American-influenced congregations implied leaving the state church, making the process difficult and complicated. Until 1891, this was a humiliating experience, whereby the convert was obliged to undergo an oral examination at the office of the parish priest and account for his or her theological reasons for leaving the state church. If the priest remained unconvinced of the seriousness of the request, he would deny permission to leave (Stensvold 2005b, 348).

Why, then, did people convert? Although social stigma waned as the new congregations grew and the dominance of the state church diminished, it was still there. What attracted new members is a complex question which merits its own study, but some preliminary conclusions may be 
drawn. The negative impact of social contempt was largely negated by the supportive social structures offered to the converts in revivalist congregations. They promoted common moral values like temperance, strict work ethics, and education, and they would also monitor practitioners' behavior. In addition, they provided solidarity, as well as protection from the conspicuous gaze of skeptical outsiders. Like other Protestant churches, they encouraged high moral standards that, in time, contributed to social mobility and shifted the majority of its members from the working class to the functionary and petite bourgeoisie. Over time, this aspect may have attracted members in its own right.

American revivalist movements, Pentecostalism in particular, are often discussed in relation to social change, and as discussed in the introductory chapter, it has been argued that they have integrated and disciplined the masses of people who have moved into new industrial settings in pursuit of work. The Norwegian case fits well into this pattern. However, it is likely that the "American touch" may have been part of these movements' appeal, including Pentecostalism. In the United States, specific theologies about the role of that country had been developed. Mormonism has a uniquely explicit American angle to its eschatology, with its members' belief that the second coming of Christ will occur in America, and the New Jerusalem will be erected there. In this particular vision, the United States replaces Israel as the point of reference and is effectively established as the land of the chosen. A similar tendency, to regard the United States as an exemplary country and endow it with a certain aura of holiness, can also be found. It is questionable whether such ideas would have attracted Norwegian converts. Still, it may well be the case that accounts of religious freedom, new revivals, and pluralism that the Norwegian immigrants and visitors to the United States sent back to Norway had an appeal, and that becoming a Pentecostal (or a Baptist) meant acquiring a piece of the American dream"the promised land," the land of plenty, a symbol of hope and a better future.

\section{Concluding Remarks and Later Developments}

In Norway today, congregations and churches rooted in Americaninfluenced revivals count approximately $80,000-100,000$ members; that is, slightly under the reported number of Catholics in Norway, and almost double the number of members of congregations that came out of domestic initiatives. Comparing their historical development, they have followed 
similar trajectories of success-or the lack thereof. In 1884, 10 years after it was founded, The Evangelical-Lutheran Free Church (Den EvangeliskLutherske Frikirke) counted 1000 members. Twenty years later, that number had grown to 3200 . Today it has 20,000 members and is the largest of the churches with domestic origins (Kristiansen and Lund 1993). The Pentecostal Movement (Pinsebevegelsen) is bigger, and is the denomination that descends directly from the movement of the early twentieth century. Regardless of how one looks at it, however, the impact of nonstate Christian initiatives in Norway has been limited. There are several reasons that may account for this, but secularization and the dominant position of the state church and its Inner Mission are important factors.

Historically, the state church played a crucial role in constructing a shared world and moral universe for the Norwegian population. Through obligatory confirmation (introduced in 1736), children were taught to respect authorities-God, king, parents, priest - and literacy spread to all social strata. The introduction of obligatory elementary school-for boys as well as girls - in both cities and the countryside (where it was introduced in 1860) was an important means of creating cultural consensus. With a syllabus of reading, writing, history, and Christian ethics, the schools' main focus was on the latter, which was taught through fables and children's tales as well as psalms and rhymes. Together, the state church and the school system made the country as a whole more homogenous than would otherwise have been possible outside of small communities (Anderson 1991). The demise of the state's religious monopoly (1842 and 1845) opened Norway to new religious innovation and foreign influences. Nevertheless, the state church managed to maintain its hold on the population. When Pentecostalism arrived in 1906, 99 percent of the population were state church members. The remaining 1 percent was divided among a number of churches and congregations of local or American origins.

The Inner Mission may have smoothed the path for American revivalist traditions, but its success at a time when significant number of new missions arrived in the country may also explain those organizations' relatively meager results. In other words, the Inner Mission may be seen as a formidable competitor, which combined experience-oriented religious individualism with traditional state church membership, tapping into the changing religious climate with a less radical and more familiar kind of Christianity than the American-influenced missionaries advocated.

Ironically, it seems that the Inner Mission-originally an attempt to reform and keep people in the state church-may have contributed to 
further processes that later served to undermine it. In the second half of the nineteenth century-a period of religious change, and of emissaries and traveling preachers from various groups-there was also a marked tendency toward cultural secularization. A prominent sign of this change was a radical decline in participation in state church rituals. The Bishop of Trondheim reports that: "In the Trondheim diocese there were 173,200 participants in the Eucharist in 1870 [...] In 1887 there were 104,000" (Sandvik 1998, 27, author's translation). The number of converts to other churches and congregations was too small to explain the decline. Instead, the explanation seems to be a combination of secularization on the one hand and the growing influence of the Inner Mission on the other. In this particular case, the two tendencies conflated and resulted in what can be described as an identity crisis for Norwegian Christianity: On the one hand, rising individualism fed into secularization and undermined traditions such as attending church on Sundays. On the other hand, the Inner Mission's narrow definition of "true faith" implied suspicion of religious rituals, and unwittingly fueled secularizing tendencies (Sandvik 1998). This trend was also strengthened by the Inner Mission's rhetoric, which referred to regular churchgoers as "Christians by habit" (vanekristne) or "Christians in name only" (navnekristne). This way of thinking about religion in terms of conversion and strong personal faith spread to larger segments of the population, entailing te individualization of formerly collective Christian identities. To the Inner Mission, attending church rituals out of habit, or a sense of duty, was a mockery of true faith. Religious rituals were null and void unless motivated by deeply felt belief. As a result, many state church members chose to remain at home, leaving the shaping of the Norwegian religious landscape to Pentecostals and other Americaninfluenced churches.

\section{REFERENCES}

Aagedal, Olaf, ed. 1986. Bedehuset: Rørsla, bygda, folket. Oslo: Samlaget. Albert, Jean-Pierre. 1997. Le sang et le ciel. Paris: Aubier.

Amundsen, Arne Bugge. 1995. 'En lidet forsøgt og mindre skriftlærd dreng.' Hans Nielsen Hauge. In Arv og utfordring: Menneske og samfunn $i$ den kristne moraltradisjon, ed. Svein Aage Christoffersen and Trygve Wyller, 68-89. Oslo: Universitetsforlaget.

- 2005. Mellom inderlighet og fornuft. In Norges religionshistorie, ed. Arne Bugge Amundsen, 243-294. Oslo: Universitetsforlaget. Anderson, Benedict. 1991. Imagined Communities. New York: Verso. 
Barratt, Thomas Ball. 1941. Erindringer. Oslo: Filadelfiaforlaget.

Bloch-Hoell, Nils. 1956. Pinsebevegelsen. Oslo: Universitetsforlaget.

Casanova, José. 1994. Public Religions in the Modern World. Chicago: University of Chicago Press.

Christoffersen, Svein Aage, ed. 1996. Hans Nielsen Hauge og det moderne Norge. Oslo: Norges Forskningsråd.

Eidberg, Peder A. 1981. Baptistene i Norge. In Norske frikirker. Fremvekst og konfesjonell egenart $i$ brytning med statskirkelighet, ed. Per Øverland, 52-70. Trondheim: Tapir.

Froholt, Asbjørn. 1993. De Frie Evangelsike Forsamlinger. In Kristne kirker og trossamfunn, ed. Peder Borgen and Brynjar Haraldsø, 57-68. Trondheim: Tapir.

Gilje, Nils. 1995. Haugebevegelsen og sekulariseringens dialektikk. In Arv og utfordring: Menneske og samfunn $i$ den kristne moraltradisjon, ed. Svein Aage Christoffersen and Trygve Wyller, 215-229. Oslo: Universitetsforlaget.

Gran, John W., Erik Gunnes, and Lars Roar Langset. 1993. Den katolske krike $i$ Norge: Fra kristningen til $i$ dag. Oslo: Aschehoug.

Greve, Kari. 2011. Hans Nielsen Hauges papirmøller. Nordisk Papperhistorisk Tidskrift 3: 3-7.

Gundersen, Knut T. 1996. Vision og vekst: Fremveksten av de frivillige kristne organisasjoner 1814-1940. Tidsskrift for Kirke, kultur og samfunn (1996): Appendix 3.

Hackett, Conrad, and D. Michael Lindsay. 2008. Measuring Evangelicalism: Consequences of Different Operationalization Strategies. Journal for the Scientific Study of Religion 47: 499-514.

Harding, Susan. 1993. Imagining the Last Days: The Politics of Apocalyptic Language. In Accounting for Fundamentalisms, ed. Martin E. Marty and R. Scott Appleby, 57-78. Chicago: University of Chicago Press.

Hassing, Arne. 1981. Frikirkelighet og statskirkelighet i forhold til metodismen i det nittende århundret. In Norske frikirker: Fremvekst og konfesjonell egenart $i$ brytning med statskirkelighet, ed. Per Øverland, 71-92. Trondheim: Tapir.

Klaveness, Thorvald. 1901. Den moderne indifferentisme og kirken. For kirke og kultur. In Norsk tro og tanke 1800-1940, compiled by Jan Ebbestad-Hansen, 419-423. Oslo: Tano-Aschehoug.

Kristiansen, Arne, and Jon Magne Lund. 1993. Den Evangelisk-Lutherske Frikirke. In Kristne kirker og trossamfunn, ed. Peder Borgen and Bjynjar Haraldsø, 95-110. Trondheim: Tapir.

Kvinge, Rolf H., and Per W. Nrsheim. 1993. Syvendedags-adeventistsamfunnet. In Kristne kirker og torssamfunn, ed. Peder Borgen and Brynjar Haraldsø, 259-272. Trondheim: Tapir.

Lambert, Frank. 1999. Inventing the "Great Awakening”. Princeton: Princeton University Press.

Lie, Geir. 2007. Norsk pinsekristendom og karismatisk fornyelse. Oslo: Refleks Publishing. 
Mauk, David C. 2013. Norwegians and Norwegian Americans, to 1870. In Immigrants in American History: Arrival, Adaption and Integration, ed. Elliott Robert Barkan, vol. 1. Santa Barbara: ABC-CLIO.

Mikalsen, Tor. 1993. Baptistene. In Kristne kirker og torssamfunn, ed. Peder Borgen and Brynjar Haraldsø, 41-56. Trondheim: Tapir.

Oftestad, Bernt T. 1998. Den norske statsreligion: Fra øvrighetskirke til demokratisk statskirke. Kristiansand: Høyskoleforlaget.

Østrem, Nils Olav. 2006. Norsk utvandringshistorie. Oslo: Det norske samlaget.

Rasmussen, Tarad, and Einar Thomassen. 2002. Kristendommen: En historisk innføring. Oslo: Universitetsforlaget.

Ringnes, Hege Kristin, and Helje Kringlebotn Sødal. 2009. Jehovas Vitner: En flerfaglig studie. Oslo: Universitetsforlaget.

Sandvik, Bjørn. 1998. Det store nattverdsfallet: En undersøkelse av avsperring og tilhørighet $i$ norsk kirkeliv. Trondheim: Tapir.

Schumacher, Jan. 2005. Kristendommen i høymiddelalderen. In Norges religionshistorie, ed. Arne Bugge Amundsen, 105-162. Oslo: Universitetsforlaget.

Shantz, Douglas H. 2013. An Introduction to German Pietism: Protestant Renewal at the Dawn of Modern Europe. Baltimore: Johns Hopkins University Press.

Ski, Martin. 1981. Pinsebevegelsen i Norge. In Norske frikirker: Fremvekst og konfesjonell egenart $i$ brytning med statskirkelighet, ed. Per Øverland, 117-125. Trondheim: Tapir.

Sørensen, Øystein, ed. 1998. Jakten på det norske: Perspektiver på utviklingen av en norsk nasjonal identitet på 1800-tallet. Oslo: Gyldendal.

Stensvold, Anne. 2005b. Amerikansk vekkelseskristendom i Norge. In Norges religionshistorie, ed. Arne Bugge Amundsen, 342-355. Oslo: Universitetsforlaget.

-2005c. Kulturkamp-religiøs kultur og motkultur. In Norges religionshistorie, ed. Arne Bugge Amundsen, 356-374. Oslo: Universitetsforlaget.

Taylor, Charles. 2007. A Secular Age. Cambridge, MA: The Belknap Press of Harvard University Press.

Open Access This chapter is distributed under the terms of the Creative Commons Attribution 4.0 International License (http://creativecommons.org/licenses/ by $/ 4.0 /$ ), which permits use, duplication, adaptation, distribution and reproduction in any medium or format, as long as you give appropriate credit to the original author(s) and the source, provide a link to the Creative Commons license and indicate if changes were made.

The images or other third party material in this chapter are included in the chapter's Creative Commons license, unless indicated otherwise in a credit line to the material. If material is not included in the chapter's Creative Commons license and your intended use is not permitted by statutory regulation or exceeds the permitted use, you will need to obtain permission directly from the copyright holder.

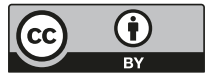

